\title{
GAMBARAN RESILIENSI KELUARGA PASIEN PENYAKIT GINJAL KRONIK YANG MENJALANI HEMODIALISIS
}

\author{
Dwi Fathun Ary Halawati ${ }^{1}$, Henni Kusuma ${ }^{1}$ \\ ${ }^{1}$ Departemen IlmuKeperawatan Dewasa, FakultasKedokteran, UniversitasDiponegoro \\ hen_hen8@yahoo.com
}

\begin{abstract}
Abstrak
Terapi hemodialisis tidak hanya memberikan masalah pada pasien, namun juga memberikan dampak pada kehidupan keluarga pasien. Tekanan yang dihadapi oleh keluarga menyebabkan stres yang cukup berat, sehingga resiliensi keluarga menjadi sangat dibutuhkan. Penelitian ini bertujuan untuk melihat gambaran resiliensi keluarga yang meliputi system keyakinan, pola organisasi keluarga dan komunikasi antar unit keluarga dalam merawat pasien hemodialisis di Kota Semarang. Penelitian ini menggunakan metode kualitatif fenomenologi dengan metode indepht interview. Informan dalam penelitian ini adalah keluarga pasien hemodialisis yang didapatkan dengan purposive sampling. Data yang dikumpulkan berupa hasil rekaman wawancara dan catatan lapangan yang dianalisis dengan metode analisa Colaizzi. Penelitian ini menghasilkan bahwa resiliensi keluarga bergantung pada sumber-sumber daya yang ada untuk digunakan dalam menyelesaikan permasalahan pasien penyakit ginjal kronik. Keluarga dianggap resilien jika mampu beradaptasi dan mencapai keseimbangan dalam keluarga, sehingga untuk mewujudkan resiliensi keluarga dibutuhkan peran aktif setiap anggota keluarga dalam memberikan perawatan pada pasien. Dukungan perawat juga diperlukan, diharapkan perawat melakukan skrining awal dan memberikan konseling pada keluarga pasien.
\end{abstract}

Kata Kunci: resiliensi, keluarga, hemodialisis

\begin{abstract}
Description of family resilience which includes belief systems, family organizational patterns and communication between family units in treating hemodialysis patients. Hemodialysis therapy not only gives problems to patients, but also has an impact on the patient's family life. The pressure faced by the family causes considerable stress, so the resilience of the family becomes urgently needed. This study aims to look at description of family resilience which includes belief systems, family organizational patterns and communication between family units in treating hemodialysis patients in Semarang City. This study uses qualitative phenomenological method with indepth interview method. The informants in this study were families of hemodialysis patients who were obtained by purposive sampling. Data collected in the form of interview records and field notes were analyzed by Colaizzi analysis method. This study resulted in family resilience depending on available resources to be used in solving the problems of patients with chronic kidney disease. The family is considered resilient if it is able to adapt and achieve balance in the family, so to realize family resilience it takes an active role for each family member in providing care to patients. Nurse support is also needed, it is hoped that nurses conduct initial screening and provide counseling to the patient's family.
\end{abstract}

Keywords: resilience, family, hemodialysis

\section{Pendahuluan}

Keluarga sebagai caregiver akan mendapatkan beberapa masalah selama merawat pasien hemodialisis, baik dari aspek psikologis, sosial, dan ekonomi. Keluarga yang hidup bersama dan menyediakan perawatan pada pasien hemodialisis dapat menciptakan ketegangan pada seluruh unit keluarga. Merawat pasien hemodialisis juga dapat memberikan pengaruh yang mendalam pada sistem keluarga, khususnya pada peran keluarga. Perubahan peran yang terjadi dapat memberikan efek stres pada pasangan dan anggota keluarga yang lainnya.

Indonesia Renal Registry (IRR) melaporkan jika 24\% keluarga yang merawat pasien hemodialisis lebih banyak terjadi argumen di dalam keluarga. Pendapat lain juga mengatakan bahwa penyakit kronik dapat pula menyebabkan kerusakan dalam pernikahan. Oleh karena 
itu, resiliensi keluarga menjadi sangat dibutuhkan. Resiliensi keluarga merupakan kemampuan keluarga dengan memperkuat dan meningkatkan pengetahuan untuk menahan dan menghadapi tantangan hidup. ${ }^{4}$ Resiliensi keluarga tidak dapat dipisahkan dari faktor resiko dan faktor pelindung. Faktor lain yang mempengaruhi resiliensi seperti, durasi lama menghadapi kesulitan, tahap perkembangan keluarga, dan sumber dukungan.

Studi pendahuluan dilakukan pada empat orang keluarga pasien hemodialisis di Unit Hemodialisis RSU Roemani pada tanggal 6 Januari 2017. Keluarga pasien mengatakan bahwa keluarga mengalami masalah ekonomi dan sosial selama merawat pasien. Informasi yang didapatkan dari perawat bahwa penelitian yang ada selama ini lebih banyak menjadikan perawat atau pasien sebagai informannya.

Fenomena diatas melatarbelakangi peneliti untuk melakukan penelitian dengan menggunakan pendekatan kualitatif pada keluarga pasien hemodialisis. Karena pendekatan kualitatif dapat mengetahui lebih dalam gambaran pengalaman hidup manusia. Penelitian ini berfokus pada pengalaman keluarga pasien hemodialisis dalam menghadapi krisis yang terjadi selama merawat pasien. Sehingga muncul gagasan penelitian mengenai gambaran resiliensi keluarga pasien penyakit ginjal kronik yang menjalani terapi hemodialisis di Kota Semarang.

\section{Metode}

Metode penelitian ini adalah penelitian kualitatif dengan pendekatan fenomenologi. Populasi dalam penelitian ini adalah keluarga pasien hemodialisis di RSU Roemani Semarang sebanyak 50 keluarga yang menjadi caregiver utama. Penentuan informan dalam penelitian ini bersifat purposive sampling.Informan pada penelitian ini berjumlah 3 keluarga dimana setiap keluarga dipilih 2 anggota keluarga, sehingga total informan adalah 6 orang.Proses wawancara dilaksanakan di rumah informan atau tempat yang telah disepakati antara informan dan peneliti. Instrumen penelitian ini adalah peneliti, pedoman wawancara, alat perekam, dan alat tulis. Pengumpulan data dilakukan dengan menggunakan teknik indepht interview. Proses wawancara membutuhkan waktu sekitar 45 menit-1 jam dalam sekali wawancara pada satu informan. Peneliti melakukan analisa data dengan metode Colaizzi. Peneliti dalam memvalidasi data menggunakan triangulasi teori dan auditing dengan dosen pembimbing.

\section{Hasil}

Informan dalam penelitian ini merupakan keluarga pasien penyakit ginjal kronik yang menjalani terapi hemodialisis di Rumah Sakit Roemani Semarang. Keenam informan diketahui beragama Islam dan berasal dari suku Jawa dengan rata-rata pendapatan keluarga perbulannya lebih dari lebih dari Upah Minimum Regional (UMR) di Kota Semarang.

Tabel 1. Karakteristik Informan

\begin{tabular}{cccccccc}
\hline Kode & Inisial & $\begin{array}{c}\text { Usia } \\
(\mathrm{Th})\end{array}$ & $\begin{array}{c}\text { Hub. } \\
\text { Dengan } \\
\text { Pasien }\end{array}$ & $\begin{array}{c}\text { Lama } \\
\text { HD }\end{array}$ & $\begin{array}{c}\text { Pendidikan } \\
\text { Terakhir }\end{array}$ & Pekerjaan & $\begin{array}{c}\text { Tipe } \\
\text { Keluarga }\end{array}$ \\
\hline P1 & Ny. S & 55 & Istri & 6 bln & Tidak Sekolah & IRT & Nuclear \\
\hline P2 & Nn. N & 29 & Anak & 6 bln & Sarjana & Pegawai Swasta & Nuclear \\
\hline P3 & Ny. M & 53 & Istri & 10 bln & Tidak Sekolah & Buruh & Extended \\
\hline P4 & Ny. P & 29 & Anak & 10 bln & SMA & Pegawai Swasta & Extended \\
\hline P5 & Ny. Si & 48 & Istri & 2 th & SMP & IRT & Extended \\
\hline P6 & Ny. E & 28 & Anak & 2 th & Diploma & Swasta & Extended \\
\hline
\end{tabular}




\section{a. Makna kesulitan bagi keluarga}

Lima informan tidak dapat memprediksi bahwa hemodialisis akan menyebabkan beberapa masalah didalam keluarga. Empat informan menunjukkan jika mereka belum siap menghadapi kemungkinan terburuk yang mungkin akan terjadi. Hal tersebut ditunjukan dalam pernyataan "Yo ndak ngira lah, saya kira dulu itu Bapak cuman harus cuci darah sekali aja eh nggak tahunya harus sampe sekarang dan nggak tahu sampe kapan. Ibu nggak ngira sampe kayak gini”. Informan kedua dan keempat mengungkapkan bahwa kesulitan merupakan hal wajar yang terjadi di dalam kehidupan. Seperti yang dikatakan oleh P2 "Menurut saya ya ini cobaan dari Tuhan untuk keluarga saya setiap orang juga punya cobaannya masing-masing”. Keenam informan juga mengatakan terdapat beberapa hikmah yang didapatkan selama merawat pasien hemodialisis, seperti yang diungkapkan oleh P5 yang mengatakan "Jadi lebih dekat satu sama lain lebih jadi orang yang sabar sama legowo (ikhlas) menjalani cobaan dari Allah. Bapak jadi bisa istirahat kerjanya".

\section{b. Pandangan positif keluarga mengenai masa depan}

Semua informan memiliki harapan untuk kesembuhan pasien dan keadaan pasien yang kondusif, sehingga pasien dapat beraktifitas seperti sebelum menjalani terapi hemodilisis. Hal terssebut ditunjukan dalam pernyataan "Harapannya yang pastinya Bapak sehat, pengennya Bapak bisa aktifitas seperti dulu lagi". Motivasi didapatkan informan dari orang-orang terdekat dan pasien lainnya yang membuat mereka merasa tidak sendiri. Hal tersebut diungkapkan oleh P4 yang mengatakan "penyakit ini tidak hanya Bapakku tok yang ngalami, bahkan ada yang lebih parah lagi”.

\section{c. Pengaruh transenden dan spiritualitas}

Informan ketiga mengatakan jika masih percaya dan masih melakukan ritualritual khusus yang dipercayai mampu memberikan kesembuhan kepada pasien. Hal tersebut dibuktikan dengan pernyataan "Ya karena kepengen sembuh hahaha, kita ya percaya kayak gitu ya percaya rumah sakit Mbak". Informan pertama dan kelima mengatakan mendapatkan ketenangan hati ketika mendekatkan diri pada Tuhan. Beberapa informan mengatakan jika tidak terjadi peningkatan dalam melakukan kegiatan keagmaan. Hal tersebut ditunjukan pada pernyataan "Ngerjain yang wajibwajib aja,.........Penyakit itu datangnya dari Allah. Kalau saya percayanya sakit Bapak itu kesempatan yang diberikan Allah untuk menghapus dosa Bapak dulu waktu masih sehat.

\section{d. Fleksibelitas}

Secara umum informan telah beradaptasi dengan masalah-masalah yang muncul selama merawat pasien hemodialisis. Informan mampu beradaptasi dipengaruhi oleh lamanya merawat pasien. Hal tersebut dapat dilihat dari pernyataan "Awalnya ya takut ya Mbak, namanya orang baru nggak tahu apa-apa. Lihat alatalatnya aja udah takut. Sekarang udah tahu gimana itu HD ya udah terbiasa”. Informan kelima dan keenam mengatakan jika mereka melakukan kegiatan diluar rumah yang bertujuan untuk mengurangi rasa jenuh yang dirasakan oleh pasien. Seperti yang dikatakan oleh P5 yang mengatakan "Kadang-kadang sekeluarga pergi makan keluar, biar Bapak nggak jenuh dirumah".

\section{e. Keterhubungan/Kohesi dalam keluarga}

Semua informan mengatakan jika mereka tidak merasa terbebani dengan peran tambahan yang dijalani. Hal tersebut ditunjukan pada pernyataan "Dulu mereka 
yang merawat saya sekarang gantian saya yang merawat mereka. Kalau saya kesuami dan keanak saya, merawat mereka itu semua adalah kewajiban saya sebagai istri dan ibu, jadi menganggap itu bukan suatu beban ya Mbak".

\section{f. Sumberdaya sosial dan ekonomi yang dimiliki keluarga}

Hubungan informan dengan keluarga besar, teman, dan masyarakat secara umum terjalin dengan baik. Hal tersebut ditunjukkan pada pernyataan "Hubungan sama keluarga besar alhamdulillah baik Mbak. Sama temen-temen juga, tetangga juga baik-baik semua”. Informan mengatakan mendapatkan dukungan dari keluarga besar, teman, dan masyarakat baik berupa materi maupun non materi, seperti yang diungkapkan oleh P1 yang mengatakan "Pulang-pulang itu pada nganterin lauk sama sayur kadang juga ada yang bawain buah-buahan Mbak. Mereka tahu pulang dari rumah sakit mesti capek nggak sempat masak. Kalau bapak diopname mereka juga njenguk ngasih uang juga". Informan mengatakan bahwa untuk menjaga kemanan finansial keluarga mereka memiliki asuransi kesehatan BPJS. Hal tersebut dapat dilihat dari pernyataan "Ya...pinjam saudara atau tempat kerja Mbak. Nanti dikembalikan pas gajian atau pas dapet rejeki lainnya......Cuci darah kalau seminggu dua kali itu bisa habis 3 jutaan, belum lain-lainnya. Jadi BPJS itu sangat membantu sekali”.

\section{g. Kejelasan komunikasi dalam keluarga \\ Pada tema ketujuh, peneliti menemukan satu sub tema yaitu pola komunikasi dalam keluarga. Informan kedua dan keenam mengatakan bahwa komunikasi yang dilakukan adalah komunikasi terbuka. Hal tersebut ditunjukkan dalam pernyataan "Kita itu apa-apa cerita Mbak, jadi nggak ada yang ditutup-tutupi gitu”.}

\section{h. Pengungkapan perasan atau emosi yang dirasakan \\ Keenam}

informanmengungkapkanemosinegatif, keenaminformantidakmenunjukkansikapde kstruktif. Hal tersebut ditunjukan dalam pernyataan "Biasanya tidur, nangis sama dengerin musik paling itu sih Mbak........ Paling diem aja sih, habis itu reda sendiri marahnya". Secara umum informan memiliki orang yang dipercayai untuk bercerita mengenai kesulitan yang dialami. Seperti yang diungkapkan oleh P3 “Kaleh lare-lare (sama anak-anak), kaleh mbak yu kulo (sama kakak perempuan saya)".

\section{i. Pemecahan masalah secara kolaboratif}

Pada tema kesembilan yang diangkat oleh peneliti, peneliti menemukan dua sub tema dalam tema ini, yaitu pembagian tugas dalam keluarga dan mempersiapkan tindakan ketika menemui tantangan yang tidak terduga. Empat informan menyatakan bahwa tidak ada pembagian tugas yang spesifik didalam keluarga. Hal tersebut ditunjukkan dalam pernyataan "Nggak dibagi-bagi gitu Mbak, secara otomatis gitu nggak usah disuruh-suruh udah tahu Mbak. Ya tahu sendiri lah Mbak, itu udah tugas sehari-hari nggak perlu dibagi-bagi lagi”.

\section{Pembahasan}

\section{a. Makna kesulitan bagi keluarga}

Nopriyanti, $\mathrm{dkk}^{7}$ mengatakan bahwa pengetahuan merupakan salah satu faktor yang mempermudah perilaku seseorang sehingga memungkinkan partisipan untuk mencegah terjadinya penyakit ginjal kronik. Ketika keluarga memiliki pengetahuan yang baik, keluarga akan mampu memprediksikan masalah sehingga dapat membantu keluarga dalam mempersiapkan keputusan yang akan diambil, termasuk kesiapan dalam menghadapi kemungkinan terburuk. Widyowati $^{8}$ menjelaskan bahwa kehilangan seseorang yang berharga 
memerlukan suatu kesiapan dan penyesuaian diri. Berdasakan hal itu maka diperlukan suatu kemampuan untuk mengatasi masalah secara positif yang ditunjukkan dengan menganggap hal tersebut sebagai sesuatu yang wajar. Asti,dkk ${ }^{9}$ mengatakan ketika menemukan hikmah dari kesulitan merupakan bentuk dari reframing. Reframing yaitu kemampuan individu untuk merangkai ulang kejadian untuk mengurangi stres yang terjadi.

\section{b. Pandangan positif keluarga mengenai masa depan}

Walsh memaparkan bahwa keluarga yang berpandangan positif adalah keluarga yang memiliki harapan. Harapan merupakan keyakinan yang berorientasi dengan memandang masa depan secara optimis, percaya diri dalam menghadapi masalah, dan memaksimalkan kekuatan serta potensi yang dimilikinya. Motivasi sebagai kondisi internal yang membangkitkan kita untuk bertindak, mendorong kita mencapai tujuan tertentu dan membuat kita tetap tertarik dalam kegiatan tertentu. ${ }^{10}$ Dukungan dari kelompok yang berisikan penderita penyakit yang sama, dapat secara efektif meningkatkan pengetahuan tentang kondisi yang dirasakan secara nyata diantara anggota. Bagi pasien PGK mengetahui bahwa yang mengalami penyakit tersebut bukan hanya dia seorang diri mampu berpengaruh terhadap perbaikan kualitas hidup pasien. ${ }^{11}$ Handayani dan Dewi ${ }^{12}$ menunjukkan bahwa kualitas hidup pasien yang menurun dapat mempengaruhi semangat hidup keluarga yang mengasuh.

\section{c. Pengaruh transenden dan spiritualitas}

Simanjuntak $^{13}$ menjelaskan jika tingkat pendidikan yang dimiliki tidak akan mempengaruhi sikap ke arah perubahan terhadap pelaksanaan upacaraupacara tradisi. Marzuki ${ }^{14}$ mengatakan jika pada prinsipnya masyarakat Jawa adalah masyarakat yang religius, masyarakat Jawa yang mayoritas beragama Islam hingga sekarang pun belum bisa meninggalkan tradisi dan budaya Jawanya. Annisa ${ }^{15}$ mengatakan jika agama/keyakinan juga berperan dalam cemas atau tidaknya seseorang. Orang yang mempunyai keyakinan agama yang kuat akan lebih sukar stres atau sebaliknya.

\section{d. Fleksibelitas}

Kemampuan keluarga untuk menerima situasi dan beradaptasi secara langsung akan mempengaruhi kondisi emosional yang baik bagi tiap anggota dalam unit keluarga. ${ }^{16}$ Ada berbagai cara yang dilakukan pasien dalam menghadapi masalah tersebut baik secara adaptif seperti bicara dengan orang lain, mampu menyelesaikan masalah, teknik relaksasi, aktivitas, olahraga, dan lain sebagainya atau menggunakan cara yang maladaptif seperti minum alkohol,reaksi lambat atau berlebihan, menghindari, mencederai diri atau lain sebagainya. $^{17}$ Apabila, mekanisme koping berhasil, maka orang tersebut akan dapat beradaptasi terhadap perubahan yang terjadi. ${ }^{19}$ Selain sebagai proses adaptasi keluarga, koping juga berfungsi sebagai sarana untuk menjaga kestabilan keluarga. ${ }^{19}$

\section{e. Keterhubungan atau kohesi dalam keluarga}

Resiko ditinggalkan oleh anggota keluarga dapat terjadi pada pasien hemodialisis karena adanya peningkatan beban yang dialami oleh caregiver. Selainperubahankondisipasien yang menjadibebankeluarga,

biayaterapihemodialisis

yang cukupbesarakanmenjadibebanbagipasienda nkeluarga. ${ }^{20}$ Setawati ${ }^{21}$ dalam penelitiannya mengenai kesabaran anak dalam merawat orang tua yang sakit kronik mengatakan bahwa merawat orang tua, terlebih merawat orang tua yang sakit merupakan suatu kewajiban bagi anak. 


\section{f. Sumberdaya sosial dan ekonomi mengenai masa depan}

Hampir setiap orang tidak mampu menyelesaikan masalah sendiri, tetapi mereka memerlukan bantuan orang lain. ${ }^{18}$ Nursalam ${ }^{10}$ mengatakan, dukungan sosial sebenarnya memerankan suatu peranan yang sangat penting dalam memberikan dukungan pada keluarga yang sedang menghadapi stressor. Ambarwati dan Widaryanti $^{22}$ membuktikan jika dukungan sosial yang diterima oleh keluarga rendah, maka nilai stres keluarga dalam kategori sedang. Bentuk dukungan akan lebih efektif tergantung pada suatu kondisi tertentu. Keamanan finansial sangat penting untuk membentuk resiliensi. Sebab sebuah penyakit serius dapat mengakibatkan terkurasnya sumberdaya ekonomi keluarga. ${ }^{4}$

\section{g. Kejelasan komunikasi dalam keluarga}

Komunikasi interpersonal yang tidak efektif dapat menyebabkan adanya kecemasan dan ketegangan pada diri individu. Penelitian yang dilakukan oleh Wijaya $^{23}$ membuktikan bahwa Komunikasi interpersonal yang berlangsung secara intensif dengan mengutamakan aspek kuantitas dan kualitas yang seimbang, akan menciptakan hubungan interpersonal yang kuat, sehingga keterbukaan dan kepercayaan yang didapat dari proses komunikasi tersebut. Asmaya ${ }^{24}$ dalam penelitiannya mengenai komunikasi terbuka dan keharmonisan keluarga memaparkan bahwa komunikasi terbuka dapat menghantarkan keluarga menjadi harmonis.

\section{h. Pengungkapan perasaan atau emosi yang dirasakan}

Saptoto mengatakan bahwa individu yang memiliki kecerdasan emosi tinggi akan memiliki kemampuan coping adaptif yang tinggi juga. Ketika kita dapat menceritakan bagaimana perasaan kita dan juga melihat bagaimana teman-teman bertingkah laku sesuai dengan perasaan mereka. Hal tersebut mampu memberikan tambahan energi untuk mengatur emosiemosi yang kadang-kadang menjadi sukar bagi kita. Mengatur emosi yang rendah dan perilaku menjalin interaksi dengan orang lain menyebabkan gangguan perilaku, sehingga memilih tindakan agresif sebagai strategi untuk keluar dari masalah. ${ }^{26}$

\section{i. Pemecahan masalah secara kolaboratif}

Sefrina dan Latipun $^{27}$ dalam penelitian mereka menjelaskan bahwa kerjasama antar anggota keluarga sangat dibutuhkan dalam pemecahan masalah bila ada krisis. Salah satu cara membentuk sebuah keluarga harmonis adalah menanamkan kesadaran akan tugas, hak dan tanggung jawab masing-masing anggota keluarga. Tentunya pembagian tugas harus disesuaikan dengan kapasitas masing-masing anggota keluarga. Apabila setiap anggota keluarga memiliki peran dan menjalankan perannya masing-masing, maka rasa terlibat dan memiliki akan terus tumbuh dan akan memupuk kekompakan keluarga. ${ }^{28}$

\section{Simpulandan Saran}

Keluarga dalam memaknai kesulitan dapat dipengaruhi oleh tingkat pengetahuan keluarga dan bagaimana keluarga memandang kesulitan sebagai sesuatu hal yang wajar serta kemampuan keluarga dalam menemukan dampak positif dari kesulitan yang terjadi. Harapan mampu memberikan kepercayaan diri keluarga dalam menghadapi masalah. Peningkatan keyakinan pada Tuhan memberikan ketenangan hati dan memberikan keyakinan pada keluarga bahwa kesulitan yang terjadi merupakan salah satu cara penebusan dosa. Perubahan adaptif keluarga dapat dilihat dari bagaimana keluarga melakukan koping. Perubahan peran yang terjadi tidak selalu meningkatkan beban pada keluarga. 
Hubungan sosial yang baik dapat memudahkan keluarga untuk meminta bantuan. Keluarga dalam menjaga keamanan finansial mereka, dengan mengikuti program BPJS. Komunikasi terbuka didalam keluarga mampu membangun keharmonisan keluarga. Teman bercerita diperlukan sebagai salah satu cara untuk mendapatkan tambahan energi dan belajar untuk mengendalikan emosi negatif. Pembagian tugas harus memperhatikan kapasitas masing-masing anggota keluarga. Diharapkan Perawat dapat memberikan inovasi seperti mengadakan kegiatan rutin yang dapat diikuti oleh keluarga pasien untuk memberikan pendidikan kesehatan mengenai manajemen stres keluarga pasien hemodialisis, selain itu perawat juga dapat memberikan konseling kepada keluarga yang dianggap kurang resiliensi dari hasil skrining yang telah dilakukan sebelumnya

\section{DaftarPustaka}

Agustina K, Dewi TK. Strategi coping pada family caregiver pasien gagal ginjal kronis yang menjalani hemodialisis. Psikologi Klinis dan Kesehatan Mental. 2013;2(3):7-13.

Ali HZ. Pengantar keperawatan keluarga. Jakarta: EGC; 2010.

Ambarwati B, Widaryati. Hubungan dukungan sosial dengan stres pada keluarga pasien yang dirawat di ruang Intensive Care Unit (ICU) RS PKU Muhammadiyah Yogyakarta. Sekolah Tinggi Ilmu Kesehatan Aisyiyah Yogyakarta; 2013.

Annisa KN. Gambaran tingkat kecemasan keluarga pasien di instalasi gawat darurat (igd) rsud panembahan senopati bantul. 2014;

Apostelina E. Resiliensi keluarga pada keluarga yang memiliki anak autis. 2011;1-11.

Arafat R. Pengalaman pendampingan keluarga dalam merawat anggota keluarganya pada kondisi vegetative dalam konteks asuhan keperawatan di RSUP Fatmawati Jakarta. Universitas Indonesia; 2010.

Asmaya E. Komunikasi terbuka melanggengkan keutuhan dan keharmonisan keluarga. Komunikasi. 2007;1(2)

Asti AD, S.Hamid AY, Putri YSE. Gambaran perubahan hidup klien gagal ginjal kronis yang menjalani hemodialisis. kebidanan dan keperawatan. 2014;10(2):172-82.

Azizah L. Keperawatan jiwa (aplikasi praktik klinik). Yogyakarta: Graha Ilmu; 2011.

Golics CJ, Khurshid M, Basra A, Salek MS, Finlay AY. The impact of patients' chronic disease on family quality of life: an experience from 26 specialties. Int $\mathbf{J}$ Gen Med. 2013;6:787-798.

Handayani DY, Eka DD. Analisis kualitas hidup penderita dan keluarga pasca serangan stroke (dengan gejala sisa). Psycho Idea. 2009;7(1).

Lestari S. Psikologi Keluarga Penanaman nilai dan penanganan konflik dalam keluarga. Jakarta: Kencana Prenada Media Group.; 2012.

Marzuki. Tradisi dan budaya masyarakat jawa dalam perspektif islam. kaji masal pendidik dan ilmu sos. 2006;

Muawanah LB, Pratikto H. Kematangan emosi, konsep diri dan kenakalan remaja. J Psikol. 2012;7(2):490-500.

Mugihartadi, Rosa EM, Afandi M. Efektivitas self help group terhadap kualitas hidup pada pasien gagal ginjal kronik. Pros Interdiscip Postgrad Student Conf. 2016; 
Noviriyanti D, Hasibuan P, Handini M. Tingkat pengetahuan, sikap dan tindakan keluarga pasien hemodialisis mengenai gagal ginjal kronik di RSUD Dokter Soedarso Pontianak. 2014;

Nugraha NJ. Pengalaman keluarga dalam merawat anggota keluarga yang menjalani terapi hemodialisis di kota bandung. Universitas Indonesia; 2010 .

Nursalam, Efendi F. Pendidikan dalam keperawatan. I. Jakarta: Salemba Medika; 2008.

Nursalam, Kurniawati ND. Asuhan keperawatan pada pasien terinfeksi HIV/AIDS. 1st ed. Jakarta: Salemba Medika; 2007.

Saptoto R. Hubungan kecerdasan emosi dengan kemampuan coping adaptif. J Psikol. 2010;37(1):13-22.

Sefrina F, Latipun. Hubungan dukungan keluarga dan keberfungsian sosial pada pasien skizofrenia rawat jalan. Jurnal Ilmu Psikologi Terapan. 2016;4(2):140-60.

Setiawati B. Kesabaran anak dalam merawat orang tua yang sakit kronis. Universitas Muhammadiyah Surakarta; 2009.

Simanjuntak BA. Tradisi, agama, dan akseptasi modernisasi pada masyarakat pedesaan Jawa. Jakarta: Yayasan Pustaka Obor Indonesia; 2016. 194 p.

Suprajitno. Asuhan keperawatan keluarga : aplikasi dalam praktik. Ester $\mathbf{M}$, editor. Jakarta: EGC; 2004.

Walsh F. Normal family process : growing diversity and complexity. New York: The Guilford Press; 2003.

Walsh F. Strengthening family resilience. 2nd ed. New York: The Guilford Press; 2006.

Widyowati W. resiliensi pada lansia yang ditinggal mati pasangan hidupnya. Universitas Muhammadiyah Surakarta; 2013.

Wijaya IS. Komunikasi interpersonal dan iklim komunikasi dalam organisasi. J Dakwah Tabligh. 2013;14(1):11526. 